\section{Henry Gray and John \\ Fraser: Scottish surgeons of the Great War}

\section{Tom Scotland}

\section{Retired Orthopaedic Surgeon}

\section{INTRODUCTION}

Between 1914 and 1918, the British Expeditionary Force fighting in France and Flanders sustained 2.7 million battle casualties. Just over one quarter $(26.1 \%)$ were never seen by the medical services. These were men who had been killed (14.2\%), were missing $(5.4 \%)$, or were prisoners of war $(6.5 \%)$. Most of those who were missing had been killed and their bodies never recovered. Just under three-quarters of the wounded (73.9\% or 1988969$)$ were seen and treated by the medical services and 151356 died. ${ }^{1}$ The worst single day in British military history was Saturday 1 July 1916, the first day of the Battle of the Somme, when there were 57470 casualties, of whom 20000 were killed or died from their wounds. In nearly a quarter of a million admissions dealt with by the medical services, $58.5 \%$ of wounds were caused by high-explosive shellfire, $39 \%$ by bullets (mostly from machine guns), $2 \%$ by grenades, and $0.5 \%$ by bayonets.

\section{Musculoskeletal wounds}

In the early months of the war, the management of musculoskeletal wounds was hopelessly inadequate. After receiving first aid from regimental medical officers in regimental aid posts immediately behind the front line, the wounded were dealt with by a field ambulance. This was a medical facility located close to the front line. It was composed of ten officers and 224 men, who either worked in a tent division or a stretcher-bearer division, each made up of three identical sections. Three field ambulances served an infantry division of 12000 men. The tent sections of the ambulances combined resources to establish an advanced dressing station (ADS) approximately 2 miles behind the front line and a main dressing station (MDS) a further 2 miles to the rear. The wounded were taken from regimental aid posts to these treatment facilities by stretcher bearers of the field ambulance.

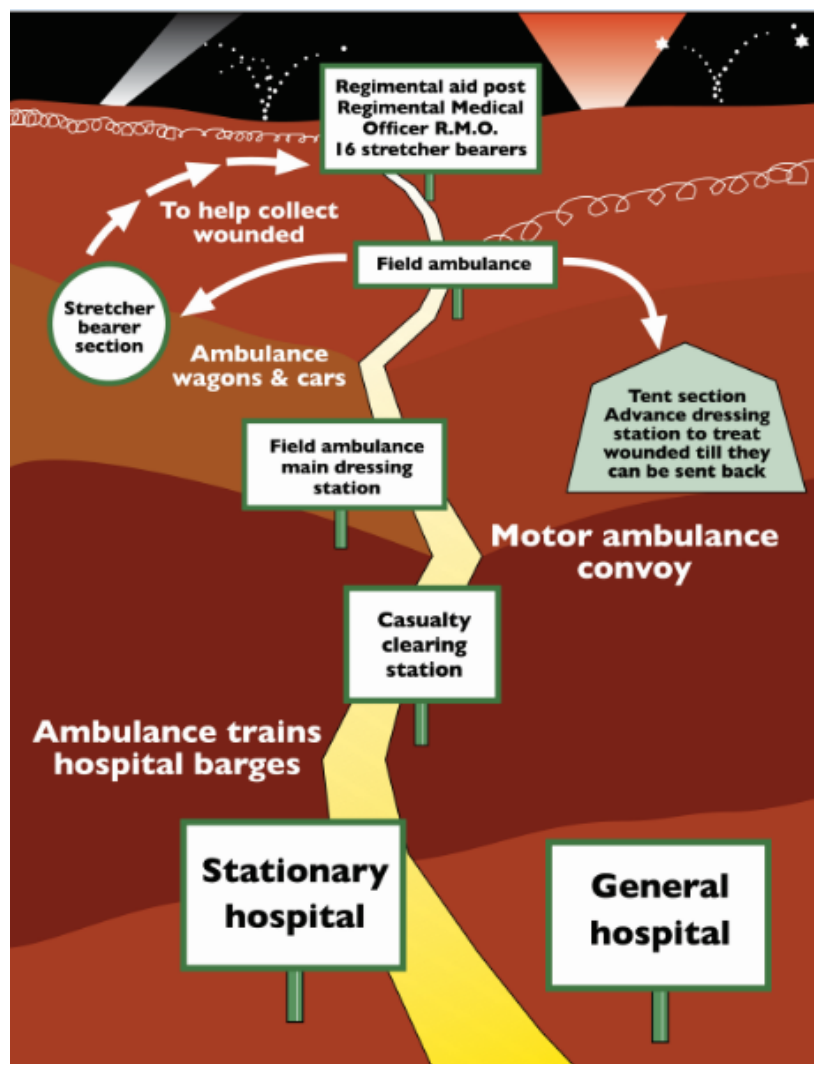

Figure 1. Evacuation pathway for the wounded

In 1914, filthy ragged wounds caused by highexplosive shellfire were often superficially disinfected and sutured in ADSs or MDSs 
before being sent along the evacuation pathway to base hospitals on or near the French coast for definitive surgical management. Such wounds were invariably heavily contaminated with fragments of shell casing, clothing, excrement, and sometimes fragments of other human beings who had been blown to pieces.

Accepted surgical practices in 1914 were based on experience derived from the Second Boer War (1899-1902), where most wounds were caused by bullets and few by shellfire. Such practices were ineffective against multiple extensive wounds caused by fragments of shell casing from high explosives. By the time patients reached base hospitals, they all had serious wound infections caused by staphylococci or streptococci and many were suffering from gas gangrene, caused by the organism Clostridium perfringens. Gangrene spreads rapidly along muscle fibres producing further muscle destruction. Gas bubbles form within the tissues, imparting a crackling sensation on palpation of the affected extremity, hence the name gas gangrene. The release of a powerful toxin soon results in multiple organ failure and death. Clostridium perfringens is an anaerobic organism, which means it only grows in the absence of oxygen, and wounds with a great deal of dead muscle, especially those of the thigh and buttock, were particularly susceptible. There were many avoidable deaths in the early months of the war, as the following quotation from the Official Australian Army Medical Services illustrates:

During the first six months of the conflict the mortality and morbidity from "septic" infection dealt to the surgical profession in every nation concerned a staggering blow,

\author{
from which it recovered only through tedious \\ and painful apprenticeship. ${ }^{2}$
}

\section{Wound excision}

New and more effective surgical methods had to be developed to combat major sepsis and a consultant surgeon from Aberdeen called Henry Gray led the way when he pioneered a procedure known as wound excision. Gray spent 3.5 years in France, at first in charge of a group of base hospitals in Rouen before becoming Consulting Surgeon to the British Third Army in 1917. First accounts of wound excision were published in June 1915 by Gray and by one of his young associates, Captain E.T.C. Milligan, an Australian, who was a graduate of Melbourne University and who was working in a field ambulance. Milligan and Gray published their work simultaneously for maximum impact, Gray in the Journal of the Royal Army Medical Corps and Milligan in the British Medical Journal. ${ }^{3,4}$ Gray went further and proposed excision and primary closure of selected wounds. ${ }^{5}$

Wound excision involves the removal of all dead and contaminated tissue from the wound. It is a procedure that has to be performed early before infection becomes established. It entails the excision of dead skin and fat, dead and contused (bruised and/or crushed) muscle and, where there are fractures, removing debris and loose pieces of bone which have lost normal soft tissue attachments. The tissues are then thoroughly cleansed and irrigated with saline solution. Even apparently minor-looking missile wounds might have been grossly contaminated by shell fragments driven into the depths of the wound. Unless all dead and contaminated tissue was completely excised and unless there was nothing left but healthy, bleeding tissue, the operation would fail, with 
potentially catastrophic consequences for the patient. Under such circumstances, overwhelming pyogenic infections and/or gas gangrene could quickly become established and result in the loss of a soldier's limb or his life.

The pioneering work of Milligan and Gray meant that limb- and life-saving surgery was performed much closer to the front line at Closer to the front line at Casualty clearing Stations (CCSs), which could be reached much more quickly. Each CCS had a basic complement of eight officers, seven nurses, and 77 other ranks. By 1917, CCSs were performing $30 \%$ of definitive surgical procedures. During the Third Battle of Ypres in 1917, for example, 379 doctors and 502 nursing sisters dealt with 201864 casualties in 24 CCSs. They operated on 61423 with a percentage mortality of $3.7 \%{ }^{6}$

\section{The place of antiseptics in wound management}

Joseph Lister, working in Glasgow Royal Infirmary, had introduced antiseptic surgery in 1865. In his first case, he applied a dressing soaked in carbolic acid to the leg of a boy with a compound fracture of the tibia. To his delight, the boy's wound healed uneventfully. Antiseptic surgery was subsequently employed extensively and effectively to reduce the incidence of wound infection by killing bacteria within the wound. Unfortunately, antiseptics alone were of little value in treating grossly contaminated wounds with massive tissue destruction caused by shellfire, although many surgeons were slow to appreciate this. The innovative work of Gray and Milligan was opposed by many surgeons who were unwilling to try something new and who continued to rely on antiseptics to deal with all such wounds. Fortunately, Gray was a very forceful individual, and wound excision prevailed against this overreliance on antiseptics. In 1918, Gray published a book entitled The Early Treatment of War Wounds. He wrote:

It cannot be emphasised too urgently that the use of antiseptics will not make up for inadequate operative treatment. It can safely also be said that the stronger the antiseptic, the worse the result. The fact should be remembered when a particularly soiled wound tempts the use of strong remedies, or when one vaunted antiseptic is tested against another. On the other hand, provided the operation is adequate, one kind of rational after-treatment does not seem to influence the patient's chance of life or limb more than another. $^{7}$

\section{Fractures of the femur}

Henry Gray soon became widely regarded as one of the best surgeons working in France. $\mathrm{He}$ developed particular expertise in the management of compound fractures of the femur, for which he documented a mortality of approximately $80 \%$ in $1914-15 .^{8}$ Compound fractures of the femur were particularly serious because of extensive muscle destruction and the loss of at least a couple of pints of blood into the thigh. The huge area of the wound with many possible recesses predisposed to foreign bodies lying undetected within its depths. Pieces of shrapnel and contaminated clothing created the ideal environment for major wound infection. Frequently, the muscle had been so badly damaged that there were areas deprived of a blood supply and therefore 
of oxygen, giving the bacteria responsible for gas gangrene an opportunity to thrive.

Splints employed to immobilize the broken bones in 1914 were not fit for purpose. The only splint mentioned for dealing with fractures of the femur in the Royal Army Medical Corps Handbook of 1911 was the rifle splint, which failed to immobilize the fracture, resulting in uncontrolled movement of the broken bone ends during transport of the patient and further excessive blood loss. Consequently, patients usually arrived at CCSs in hypovolaemic shock and unfit for limb- and life-saving wound excision.

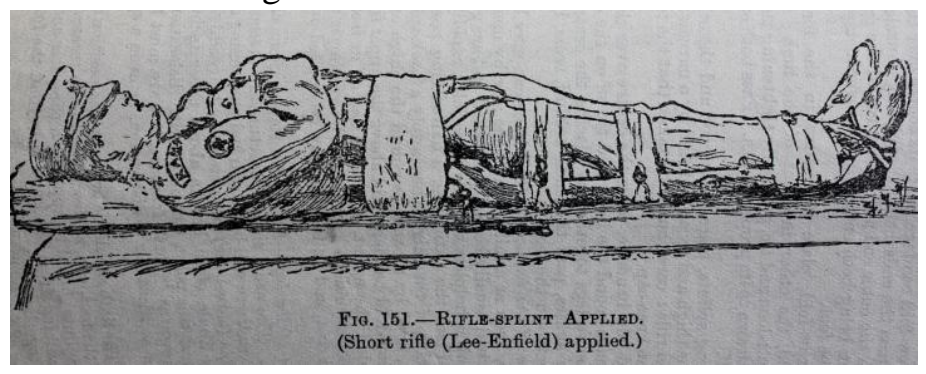

Figure 2. Rifle Splint; from Royal Army Medical Corps Handbook, 1911; a Lee-Enfield Rifle was strapped to the affected limb. It was not effective in immobilising the fracture.

There was a much better splint available called the Thomas splint, which was introduced by Gray's friend and colleague Robert Jones from Liverpool. The Thomas splint immobilized the fractured femur effectively, restricting movement at the fracture site and reducing bleeding, so that patients arrived at CCSs in good clinical condition and fit to undergo wound excision. In The Early Treatment of War Wounds, Gray reported on the outcome of 1009 cases of compound fracture of the femur admitted to CCSs during the Battle of Arras, which was fought during the months of April and May 1917. The Thomas splint was employed exclusively to immobilize the fracture. The mortality was reduced to $15.6 \%$.

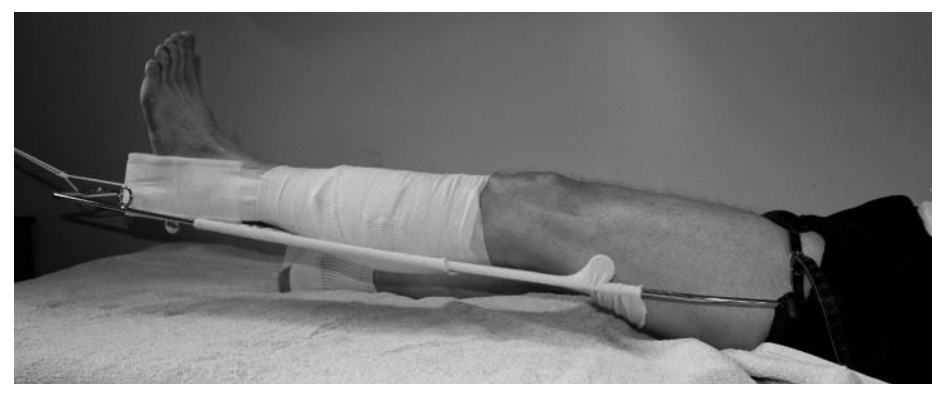

Figure 3. Thomas Splint showing how longitudinal traction is applied to the limb to overcome muscle spasm and maintain reduction of the fracture; by effectively immobilising the fracture, the Thomas Splint helped to reduce blood loss.

By 1918, Gray was the leading authority in military orthopaedics. Lieutenant-Colonel Carberry of the New Zealand Medical Services wrote:

Surgery, especially that of the front line, was a specialty of the Third Army whose Consulting Surgeon, Colonel H.M.W. Gray, was noted since 1916 for his work in the treatment of compound gunshot fractures. His memoranda, issued by the Third Army in 1917, formed the basis of the front line surgical practice of this and other armies. His well-known book, The Early Treatment of War Wounds, published at the end of 1918, epitomised the advancing knowledge of that period. His lectures given at Louvencourt were attended by all our medical officers in turn: the problems of shock prevention at the RAP and ADS, the best method of splinting fractures and the demonstration of the regulation set of splints now carried in racks by each motor ambulance, formed the basis of these lectures. ${ }^{9}$ 


\section{Penetrating abdominal wounds}

Just as Henry Gray demonstrated the need to undertake early wound excision for musculoskeletal wounds, so others showed that early laparotomy for penetrating abdominal wounds was vital to improve chances of survival. Once again, surgical methods in 1914 were based on experience from the Second Boer War, when "expectant treatment" was the standard practice. Casualties were kept warm in Fowler's position. Nothing was given orally for three days, saline was given rectally and the outcome was almost invariably fatal. The first successful bowel resection was not performed until 18 March 1915 by surgeon Owen Richards. ${ }^{10}$ This was eight months after the war had started. The patient was a Canadian Scot, wounded in the abdomen in a German trench on 18 March. He walked back to his own lines holding his protruding intestines, intending to die amongst his friends. He had six feet of small bowel with multiple perforations resected promptly and survived. Timing was crucial. ${ }^{11}$

A young and enthusiastic surgeon from Edinburgh called John Fraser was quick to recognize the need for early laparotomy in patients with penetrating abdominal wounds. Before the war, Fraser had worked extensively with Harold Styles, who was Regius Professor of Surgery at the University of Edinburgh. Fraser showed great surgical flair while working with the British Army in France and had a gift for clinical research. He was attached to the First Army whose consulting surgeon was Cuthbert Wallace. Working in CCSs in northern France, Fraser documented a $20 \%$ reduction in mortality of penetrating abdominal wounds from $80 \%$ to $60 \%$ with early intervention in a series of 300 cases. 12
Simple wounds of small bowel requiring only suture had an excellent prognosis, while those with mesenteric involvement requiring bowel resection had a mortality of $79 \%$. Large bowel wounds carried a mortality of $56 \%$, while intraperitoneal rectal wounds, with a proximal colostomy, had a mortality of $70 \%$. Extraperitoneal rectal wounds were laid open fully in an attempt to reduce devastating pelvic sepsis. Fraser and Wallace subsequently documented 2127 cases of penetrating abdominal wounds with an overall mortality of $60 \%$ and operative mortality of $50 \%$. Intervention within 6-10 hours had a much better prognosis than when delayed more than 24 hours. A pulse rate less that 100 per minute carried a good prognosis, while few with a pulse greater than 120 survived. $^{13}$

The chest was involved in $12 \%$ of abdominal wounds. ${ }^{14}$ The recovery rate of combined wounds was $18 \%$ in $1916,49 \%$ in 1917 , and $67 \%$ in $1918 .{ }^{15}$ Clinical experience, better anaesthesia, and blood transfusion contributed to the improved survival. While by modern standards the mortality still seems very high, these were very significant advances for the time.

\section{Hypovolaemic shock}

Henry Gray and John Fraser both worked on a committee set up by the MRC to improve the understanding of shock and both were engaged in clinical research to mitigate its effects. John Fraser was awarded a Military Cross after sustaining a wound while doing clinical research on shock close to the British front line, while Henry Gray opened a shock centre at British Casualty Clearing Station 3 at Gézaincourt, making blood transfusion more readily available to treat the wounded in forward areas. 


\section{Gray and Fraser after the war}

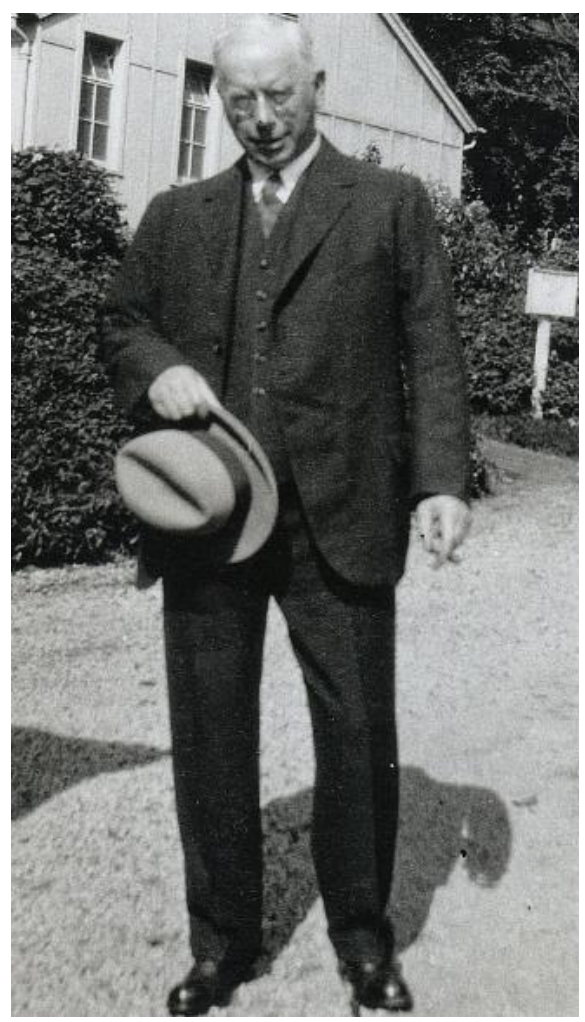

Figure 4. Sir Henry Gray (1871-1938) as an older man; courtesy Dr Ian Levack

Henry Gray returned to Aberdeen, but never settled. Perhaps he was too disturbed by his wartime experience to resume his former routine as though nothing had happened, when in fact so much had changed. He was knighted and the University of Aberdeen bestowed an Honorary Degree of LLD for his services to war surgery. He was offered, and accepted, the post of Surgeon-in-Chief to the Royal Victoria Hospital in Montreal, where sadly his career ended in surgical oblivion. ${ }^{16}$

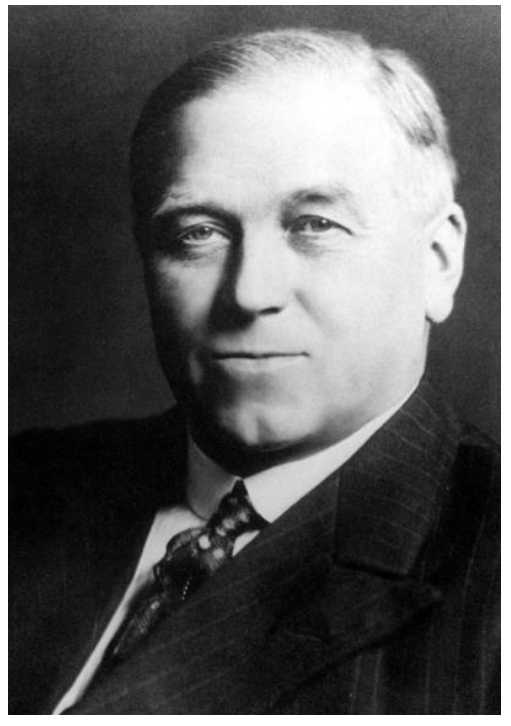

Figure 5.

Sir John Fraser (1885-1947), as an older man; courtesy Royal College of Surgeons, Edinburgh

John Fraser returned to Edinburgh, invigorated and enriched by his experience, and ready to resume his promising career. He became Regius Professor of Surgery in 1927 when the by-then Sir Harold Styles retired. Fraser was knighted in 1937, became a baronet in 1942, and Principal of the University of Edinburgh in 1944.

\section{REFERENCES}

1. Mitchell TJ, Smith GM. Medical Services: Casualties and Medical Statistics of the Great War. London, UK: His Majesty's Stationery Office; 1931.

2. Butler, AG. Official History of the Australian Army Medical Services in the War of 1914-1918. Volume II, The Western Front. Canberra, Australia: Australian War Memorial; 1940. p. 312.

3. Mulligan ETC. The early treatment of projectile wounds by excision of the damaged tissues. Br Med J. 1915;1(2843):1081.

4. Gray HMW. The treatment of gunshot wounds by excision and primary suture. $\mathrm{J} R$ 


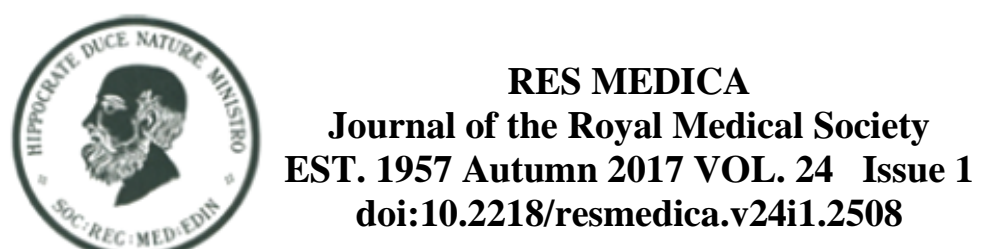

SPECIAL ARTICLES

Army Med Corps. 1915;24:551-4. DOI: 10.1136/jramc-24-06-05.

5. Gray HMW. Treatment of gunshot wounds by excision and primary suture. Br Med J. 1915; 2(2852):317. DOI:

10.1136/bmj.2.2852.317.

6. Macpherson WG. History of the Great War Based on Official Documents. Medical Services: General History. Volume 3, The medical services during the Western Front in 1916, 1917 and 1918; in Italy; and in Egypt and Palestine. London, UK: His Majesty's Stationery Office; 1924. pp. 167-9.

7. Gray HMW. The Early Treatment of War Wounds. London, UK: H. Frowde; Hodder \& Stoughton; 1919. p. 107.

8. Watson F. The Life of Sir Robert Jones. London: Hodder \& Stoughton; 1934. p.158.

9. Carberry AD. The New Zealand Medical Services in the Great War 1914-1918.

Auckland, New Zealand: Whitcombe \& Tombs; 1924. p. 399.

10. Gordon-Taylor G. The Abdominal Injuries of Warfare. Bristol, UK: John Wright \& Sons; 1939. pp. 23-4.

11. Richards $\mathrm{O}$. The pathology and treatment of gunshot wounds of the small intestine. $\mathrm{Br}$ Med J. 1915;2(2849):213-5. DOI:

10.1136/bmj.2.2849.213.

12. Fraser J, Drummond H. A clinical and experimental study of three hundred perforating wounds of the abdomen. Br Med J. 1917;1(2932):321-30. DOI:

10.1136/bmj.1.2932.321.

13. Wallace CS, Fraser, J. Surgery at a Casualty Clearing Station. London, UK: A\&C Black; 1918. p. 156.
14. Wallace CS. The Lettsomian lectures on war surgery of the abdomen. Lancet. 1917;189(4885):561-8. DOI: 10.1016/S01406736(01)28868-0.

15. Gordon-Taylor G. War wounds and air raid casualties: The abdominal injuries of warfare-II. Br Med J. 1939;2(4099):235-8. DOI: 10.1136/bmj.2.4099.235.

16. Scotland TR, Boyer A. Henry Gray: Surgeon of the Great War. Edinburgh, UK: Capercaillie Books; 201 